\title{
Hidráulica Urbana - Sistemas de Abastecimento de Água e de Drenagem de Águas Residuais
}

José Alfeu Almeida de Sá Marques e Joaquim José de Oliveira Sousa

Durante minha estadia na cidade do Porto para participar do $14^{\circ}$ Simpósio Luso Brasileiro de Engenharia Sanitária e Ambiental (SILUBESA), em outubro de 2010, tive a oportunidade de conhecer este livro, que logo me chamou atenção pela qualidade e pela forma como reúne, em um só volume, os temas da Hidráulica Urbana de interesse da Engenharia Sanitária e Ambiental.

Após uma breve introdução (Capítulo 1), seguem os outros capítulos com seus respectivos conteúdos principais:

Capítulo 2 - Elementos de Base: horizonte de projeto; estudos de evolução da população; consumos e variações de consumo; cálculo das vazões dos diferentes componentes dos sistemas de abastecimento de água e de drenagem de águas residuárias

Capítulo 3 - Adução: regras gerais sobre traçado em planta e em perfil; tipos de tubos e juntas; cálculo de perdas de carga em condutas; estudo econômico de adutora; vazão de dimensionamento; determinação da secção mais econômica; elevatórias; órgãos de manobra e segurança; assentamento das tubulações;

Capítulo 4 - Reservatórios: classificação e finalidade dos reservatórios; cálculo da capacidade dos reservatórios; aspectos funcionais e construtivos

Capítulo 5 - Sistemas de Distribuição de Água: traçado e tipos de redes de distribuição; condições prévias ao dimensionamento da rede; modelos matemáticos para análise de sistemas de distribuição de água; métodos numéricos de resolução; acessórios e elementos especiais; cálculo hidráulico de um sistema de distribuição;

Capítulo 6 - Transitórios Hidráulicos: classificação do escoamento; descrição física do fenômeno; regimes variáveis sob pressão; análise simplificada do choque hidráulico;

Capítulo 7 - Simulação Dinâmica de Sistemas Sob Pressão: equações do movimento; modelos de simulação dinâmica;

Capítulo 8-Modelação Matemática da Qualidade em Sistemas de Abastecimento de Água: formulação de base; modelos cinéticos de decaimento do cloro; métodos numéricos para resolução dos sistemas de equações da qualidade da água;
Capítulo 9 - Sistemas de Drenagem de Águas Residuais (os portugueses não distinguem águas residuárias e águas residuais): concepção dos sistemas de drenagem de águas residuais; constituição das redes de drenagem de águas residuais domésticas; estudo do traçado das redes; vazões de projeto; dimensionamento hidráulico-sanitário dos sistemas; implantação dos coletores:

Capítulo 10 - Sistemas de Drenagem de Águas Pluviais: caudal de águas pluviais; tempo de concentração; intensidade da chuva; tempo de recorrência ou período de retorno; coeficiente de escoamento; avaliação do caudal cálculo hidráulico dos coletores; coletores, galerias e órgãos acessórios

Capítulo 11 - Reabilitação de Condutas: técnicas para reabilitação de condutos:

Anexo 1 - Cálculo de Perdas de Carga;

Anexo 2 - Instalações Elevatórias.

Ao final de cada capítulo, encontram-se exemplos de aplicação ou de dimensionamento, ou análise comparativa dos métodos e técnicas expostos.

Sem dúvida, é um livro muito útil para projetistas e consultores no domínio da Hidráulica Urbana, mas a forma como apresenta as soluções de engenharia para as questões da hidráulica dos sistemas de abastecimento de água e de coleta (drenagem) de esgotos e águas pluviais, em um único volume, faz dele um livro muito adequado para apoiar o ensino e a pesquisa nos cursos de graduação e pós-graduação em Engenharia Civil, Sanitária, Ambiental e correlatos. Essa forma de apresentação certamente atende às necessidades acadêmicas dos autores e professores da Universidade de Coimbra, sem perder a qualidade e os aspectos práticos necessários para o projetista. Na Universidade Federal do Rio Grande do Norte, já foi indicado para as turmas de 2011 dos cursos de Engenharia Civil (disciplinas Saneamento do Meio e Sistemas Urbanos de Água e Esgotos) e do Mestrado em Engenharia Sanitária (disciplina Águas Urbanas), por dois professores desses cursos.

Pode ser adquirido acessando-se o site http://siglv.uc.pt/imprensa (vendas online). Também fica o exemplo e a motivação provocativa para nossos colegas brasileiros que têm capacidade de produzir um livro com a mesma forma, reunindo a Hidráulica Urbana em um só volume.

\section{Comentário elaborado pelo Coordenador da Coluna Livros, Professor Cícero Onofre de Andrade Neto}

A sessão "Livros", que a cada edição traz resumos comentados sobre livros de interesse na área, tem como principal objetivo permitir que o leitor, de forma rápida, se atualize e conheça o que há disponível no mercado editorial. As contribuições deverão ser encaminhadas para: resa@abes-dn.org.br 